\title{
Vasodilator activity of extracts of field Alpinia purpurata (Vieill) K. Schum and $A$. zerumbet (Pers.) Burtt et Smith cultured in vitro
}

\author{
Cristiane Pimentel Victório" ${ }^{1 *}$, Ricardo Machado Kuster², Roberto Soares de Moura ${ }^{3}$, Celso Luiz \\ Salgueiro Lage ${ }^{I}$
}

\author{
${ }^{1}$ Laboratory of Plant Physiology, Carlos Chagas Filho Institute of Biophysics, Federal University of Rio de Janeiro, \\ ${ }^{2}$ Laboratory of Phytochemistry, Natural Products Research Nucleus, Federal University of Rio de Janeiro, Department of \\ Pharmacology and Psychobiology, State University of Rio de Janeiro
}

\begin{abstract}
Nowadays, the high blood pressure is one of the main causes of death and cardiovascular diseases. Vasodilator drugs are frequently used to treat arterial hypertension. Experiments were undertaken to determine whether hydroalcoholic extracts obtained from leaves of field-grown Alpinia purpurata and A. zerumbet cultured in vitro under different plant growth regulators induce a vasodilator effect on Wistar rat mesenteric vascular bed pre-contracted with norepinephrine. Plant extracts were able to induce a long-lasting endothelium-dependent vasodilation. Efficiency on activity of $A$. purpurata reached $87 \%$ at concentration of $60 \mu \mathrm{g}$. The extract of $A$. zerumbet maintained in medium containing IAA, induced the relaxation $(17.4 \%$ ) at $90 \mu \mathrm{g}$, as compared to the control (MS0) that showed a better vasodilator effect $(60 \%)$. These results are in agreement with the quantification of phenolic compounds in the extracts, which were $50 \%$ lower for those plants cultured in IAA. A. purpurata was assayed for the first time in relation to its vasodilator activity. This paper showed a strong probability of correlation between the pharmacological activities of $A$. purpurata with their content in phenolic compounds.
\end{abstract}

Uniterms: Alpinia purpurata (Vieill) K. Schum./pharmacognosy. A. zerumbet (Pers.) Burtt et Smith./ pharmacognosy. Natural vasodilators/experimental studies. Plant extracts/vasodilator action. Plant tissue/ culture. Endothelium-dependent. Flavonoids. Medicinal Plant. Plant growth/regulators. Zingiberaceae.

Atualmente, a hipertensão arterial é uma das maiores causas de morte e de doenças cardiovasculares. Os vasodilatadores são freqüentemente utilizados no tratamento da hipertensão. Extratos hidroalcoólicos de Alpinia purpurata de campo e de $A$. zerumbet cultivada in vitro sob diferentes reguladores de crescimento vegetal foram ensaiados no leito mesentérico de ratos Wistar. Os extratos de A. purpurata e A. zerumbet produziram efeito vasodilatador com padrão de resposta dose-dependente de duração prolongada. Extratos da espécie $A$. purpurata tiveram efeito vasodilatador de $87 \%$ na dose de $60 \mu \mathrm{g}$. O extrato obtido de folhas de A. zerumbet oriundas das culturas mantidas em meio contendo AIA (ácido indol acético) inibiu o relaxamento (17,4\%) na dose de $90 \mu \mathrm{g}$ em relação ao controle (MS0), com o qual foi verificado melhor efeito vasodilatador (60\%). Estes resultados estão de acordo com a concentração de fenóis totais que foi $50 \%$ menor para os extratos de plantas cultivadas in vitro em AIA. A espécie $A$. purpurata foi pela primeira vez ensaiada quanto à atividade vasodilatadora. Os resultados obtidos indicaram a presença de substâncias fenólicas provavelmente correlacionadas à ação terapêutica de A. purpurata.

Unitermos: Alpinia purpurata (Vieill) K. Schum./farmacognosia. Alpinia zerumbet (Pers.) Burtt et Smith./ farmacognosia. Vasodilatadores naturais/estudo experimental. Extratos vegetais/ação vasodilatadora. Tecidos vegetais/cultura. Endotélio-dependente. Flavonóides. Plantas medicinais. Crescimento vegetal/ reguladores. Zingiberaceae

"Correspondence: C. P. Victório. Instituto de Biofísica Carlos Chagas Filho, Universidade Federal do Rio de Janeiro, Av. Carlos Chagas Filho, s/n, Cidade Universitária, CCS, Bloco G, sala G2-050, 21941-902 - Rio de Janeiro - RJ, Brasil. E-mail: crispv@biof.ufrj.br 


\section{INTRODUCTION}

Cardiovascular diseases are the main mortality cause in Brazil. Hypertension is characterized by blood pressure increase, related to heart effort to propel blood and the vascular resistance (Godoy et al., 2007). This disease affects people from different ages and social ranges, and there are several attempts to minimize or prevent hypertension occurrence that, in their majority, involve adequate diet, physical exercises, and medications. In Brazil, several reports have evidenced the use of plants having antihypertensive effects (Rocha et al., 2007). Alpinia zerumbet, known as 'colônia', is widely used in northeastern and southeastern Brazil as infusions or decoctions for treatment of arterial hypertension. Hypotensive effects of this species have been justified by composition of hydroalcoholic and aqueous extracts and essential oils (Soares de Moura et al., 1998; Victório et al., 2009a). According to Mendonça et al. (1991) a decrease blood pressure in rats and dogs was observed using hydroalcoholic extracts of A. zerumbet. Mpalantinos et al. (1998) suggested that flavonoids and kavapyrones are responsible for vasodilator activity of aqueous extracts of $A$. zerumbet, while Lahlou et al. (2003) attributed it to some essential oil constituents therapeutic effects of $A$. zerumbet. A similarity between Alpinia purpurata and $A$. zerumbet was found in phytochemical studies, in terms of essential oils and flavonoids composition (Victório, 2008; Victório et al., 2009b). The presence of flavonoids supported evidence for the chemosystematic features of the Zingiberiflorae, Zingiberaceae family (Pugialli et al., 1993; Victório et al., 2009b). Previous studies performed in animals have demonstrated that flavonoids are involved in vasodilator and hypotensive effects of A. zerumbet (Da Costa et al., 1998; Mpalantinos et al., 1998; Zheng-Tao et al., 2001; Lahlou et al., 2002; Lahlou et al., 2003; Soares de Moura et al., 2005).

A. purpurata is a tropical plant that possesses high value in the international market for cut flowers due to the durability and exuberance of its inflorescences, on the other hand its phytochemical investigation is still scarce and studies about its therapeutic effects are incipient. Recently, some flavonoids isolated from $A$. zerumbet have also been detected in A. purpurata extracts, what may corroborate the potential medicinal value of this species in treat arterial hypertension (Mpalantinos et al., 1998; Victório et al., 2007; Victório et al., 2009b). Flavonoids are known to possess cardioprotective properties and their isolation from different medicinal plants has exhibited antihypertensive action. Wang et al. (2004) suggested that flavonoids may act in vascular system as antiarrhythmic and vasodilator agents. Some commercialized medicines available to treat vascular diseases contain purified fractions of flavonoids, as for example, Daflon $500 \mathrm{mg}$. Flavonoids are antioxidants with health benefits acting in many hypotensive mechanisms such as inhibition of the angiotensin converting enzyme, blocking $\mathrm{Ca}^{+2}$ channels, inhibition of vasoconstrictor prostanoid synthesis and inducing relaxation elicited by bradikynin (Formica, Regelson, 1995; Pourcel et al., 2006; Havsteen, 2002; Xu et al., 2006).

Production of bioactive metabolites through plant tissue culture techniques has largely been adopted to optimize the content of terpenoids, flavonoids, alkaloids and many phenolic compounds by addition of plant growth regulators in culture media (Canter et al., 2005; Victório et al., 2008). Considering secondary metabolites production, this study also intended to evaluate vasodilator activity of plants obtained from tissue cultures of $A$. zerumbet maintained under growth regulators effects.

Tests utilizing the rat mesenteric bed allow the vasodilator evaluation of plant extracts (McNeill, Jurgens, 2006) and, depending on the results, could even suggest a hypotensive activity. The hypertension has as its main consequence, an inadequate tissue perfusion that increases the risks for cerebral vascular accidents and ischemic heart disease (Kaiser, 2004). The purpose of this work was to evaluate the vasodilator action of plants of $A$. purpurata, collected in Rio de Janeiro, and plants of A. zerumbet arose from in vitro cultures.

\section{MATERIAL AND METHODS}

\section{Animals}

All procedures concerning animals were carried out in an ethically proper way, by following guidelines as set by the World Health Organization. Experiments were also reviewed and approved by the Ethics Committee of Animal Experiments of the State University of Rio de Janeiro. Male two-month-old Wistar rats, weighing 230-260 g, were kept at constant room temperature $\left(24-26^{\circ} \mathrm{C}\right)$, under a 12-hour standard light/dark cycle, light period starting at 6 a.m., and free access to food and water.

\section{Plant material and preparation of extracts}

Samples of $A$. zerumbet and A. purpurata leaves were collected from plants growing in Rio de Janeiro, at Universidade Federal do Rio de Janeiro (Rio de Janeiro state, Brazil). Voucher specimen was identified and is deposited at the Herbarium of Rio de Janeiro Botanical Garden, under accession number RB 433485 and RB 
433484, respectively. Those $A$. zerumbet plants were used as explants donor for tissue cultures establishment according to Victório, 2008. A. zerumbet was cultured in glass bottles containing $60 \mathrm{~mL}$ of MS (Murashige, Skoog, 1962) medium, added 30 g. $\mathrm{L}^{-1}$ of sucrose, vitamins and myo-inositol. The following growth regulator treatments were evaluated for 60 days: MS0 (control); $\mathrm{MS}+2 \mathrm{mg} . \mathrm{L}^{-1}$ indole-3-acetic acid (IAA 2) and; MS +2 mg. $\mathrm{L}^{-1} \mathrm{IAA}+$ $2 \mathrm{mg} . \mathrm{L}^{-1}$ thidiazuron (TDZ 2). Cultures were maintained under white light (fluorescent tubs, $20 \mathrm{~W}, \mathrm{~T}-12$, General Electric $\left.{ }^{\circledR}\right)$, intensity of $30 \mu \mathrm{mol} \cdot \mathrm{m}^{-2} \cdot \mathrm{s}^{-1}$, daily photoperiod of 16 hours, at $25 \pm 2{ }^{\circ} \mathrm{C}$. The design of the experiments was a complete randomized block, and each experiment consisted of three explants per glass and the minimum of ten replicate culture flasks per plant growth regulator treatments.

Leaves from field-grown donor plants were dried for 3 days in stove $\left(60^{\circ} \mathrm{C}\right)$ and macerated in 50\% ethanol $(1: 20$ $\mathrm{w} / \mathrm{v})$ using ultrasonic bath $(40 \mathrm{kHz}$, Thornton Unique, model 1400 USC) for $45 \mathrm{~min}$, at $60^{\circ} \mathrm{C}$. Leaves obtained of in vitro cultures were dried by lyophilization and extracted in $50 \%$ ethanol as described above. All determinations were carried out in triplicates. The crude extracts were filtered in vacuum using a Whattman ${ }^{\circledR}$ filter $(110 \mathrm{~mm} \varnothing, 1)$ and dried by rotary evaporation.

\section{Total phenolics}

Total phenolics compounds were determined using the Folin-Ciocalteau method (Singleton, Rossi, 1965). Hydroalcoholic extracts were dissolved in ethanol (70\%) at $1 \mathrm{mg} / \mathrm{mL}$. An aliquot of $0.5 \mathrm{~mL}$ of diluted extract and 2 $\mathrm{mL}$ Folin-Ciocalteau reagent (10\%) were added, after 3 min, along with $2 \mathrm{~mL}$ of $7.5 \%$ sodium carbonate, and the contents were mixed. The mixture was homogenized and incubated at $50{ }^{\circ} \mathrm{C}$ for $30 \mathrm{~min}$. The absorbance was measured at $740 \mathrm{~nm}$ in a spectrophotometer using gallic acid as standard. Two controls were used: (1) Folin-Ciocalteau + sodium carbonate and (2) crude extract solution. The quantification of phenolic compounds in crude extracts was determined from regression equation of calibration curves: $y=0.0229 x+0.0968\left(\mathrm{R}^{2}=0.9993\right)$ and expressed as $\mathrm{mg}$ gallic acid equivalents (GAE) per $1 \mathrm{~g}$ of dried leaves. All determinations were carried out in triplicates.

\section{High performance liquid chromatography analysis}

Crude extracts were filtered in vacuum, dissolved in methanol: Milli-Q water (50\%) at $10 \mathrm{mg} / \mathrm{mL}$ (field-grown) and $50 \mathrm{mg} / \mathrm{mL}$ (in vitro cultures). HPLC-UV analyses were performed on an apparatus Shimadzu equipped with SPD-
M10A diode array detector, LC-10AD pump and CBM-10 interface. Data were acquired and processed by a reversed phase column (Lichrosorb ${ }^{\circledR} \mathrm{RP}-1825 \mathrm{~cm} \times 4.6 \mathrm{~nm}, 5 \mu \mathrm{m}$ ), room temperature. Separation was done in the following mobile phase: MilliQ water $+0.1 \%$ phosphoric acid (A) and methanol (B): $1-10 \min (30 \% \mathrm{~B}) ; 20 \min (40 \% \mathrm{~B}) ; 60$ $\min (100 \%$ B) (Victório et al., 2009b). The flow rate was kept constant at $1 \mathrm{~mL} / \mathrm{min}$ and the peaks were detected at $360 \mathrm{~nm}$. All chemical used in analysis as methanol and phosphoric acid were of HPLC grades and were purchased from Merck. MilliQ water was utilized to HPLC mobile phase and sample preparation. Standards were dissolved in methanol $70 \%$ at $1 \mathrm{mg} / \mathrm{mL}$ and analyzed in the same elution. The injections of $20 \mu \mathrm{L}$ were repeated in triplicates. Determination of the content of the flavonoids was performed by the external standard method, using authentic standards of rutin and kaempferol-3-O- $\beta$-D-glucuronide. Quantification of flavonoids in the extracts was obtained against calibration curves of standards.

\section{Isolated mesenteric vascular bed}

Experiments were undertaken to determine whether hydroalcoholic extracts obtained from leaves of fieldgrown Alpinia purpurata and A. zerumbet cultured in vitro under different plant growth regulators induce a vasodilator effect in the Wistar rat mesenteric vascular bed pre-contracted with norepinephrine. Crude extracts were dissolved in ethanol: Milli-Q water (1:1) at $1 \mathrm{mg} /$ $\mathrm{mL}$ concentration.

The rat superior MVB (Mesenteric Vascular Bed) was isolated according to McGregor (1965). Male Wistar rats were killed with inhaled $\mathrm{CO}_{2}$ and superior MVB was cannulated with a $4 \mathrm{~cm}$ polyethylene tube (PE 50, Clay Adams Brand CA - Becton Dickinson) and perfused at a flow rate $4 \mathrm{~mL} / \mathrm{min}$ with a physiological salt solution (PSS) by pulsatile pump (Life Care Pump, Model 4 - Abbott / Shaw). The PSS had the following composition (mM): $\mathrm{NaCl} 118.3 ; \mathrm{KCl} 4.7 ; \mathrm{CaCl}_{2} .2 \mathrm{H}_{2} \mathrm{O} 2.5 ; \mathrm{MgSO}_{4} .6 \mathrm{H}_{2} \mathrm{O}$ 1.2; $\mathrm{KH}_{2} \mathrm{PO}_{4} 1.2 ; \mathrm{NaHCO}_{3} 25.0$; EDTA 0.026 and glucose 11.1. The PSS $\left(37^{\circ} \mathrm{C}\right)$ was bubbled with $\mathrm{O}_{2} 95 \%$ and $\mathrm{CO}_{2} 5 \%$. Perfusion pressure (PP) was measured with a transducer connected to a preamplifier (Hewlett Packard - 7754 A) and chart recorded. Drugs were either dissolved in PSS and perfused at the desired concentration or administered as bolus injections directly into the perfusion stream (volume $<300 \mu \mathrm{L}$ ).

The preparations were left to equilibrate for $40 \mathrm{~min}$, and then injections of $120 \mu \mathrm{mol}$ of $\mathrm{KCl}$ were administered every 10 min until consistent responses were obtained. The basal perfusion pressure after the equilibration period 
oscillated between 20 and $25 \mathrm{mmHg}$. The hydroalcoholic extracts were injected in bolus after the PP had been elevated $(80-110 \mathrm{mmHg})$ with norepinephrine $(\mathrm{NE}, 30 \mu \mathrm{M})$ added to the perfusion fluid. When the pressor effect of NE reached a plateau, acetylcholine (Ach, $10 \mathrm{pmol}$ ) and nitroglycerin (NG, $10 \mathrm{nmol}$ ) were injected to test the endothelium-dependent and endothelium-independent vasodilator responses before dose-response curves to crude extracts were obtained. The vasodilator effect of drugs was expressed as a percentage decrease in relation to the pressor effect of NE. Crude extracts were administered in bolus in increasing doses $1,3,6,10,30,60$ and $90 \mu \mathrm{g}(\mathrm{n}=6)$.

\section{Statistical Analysis}

The vasodilator effect of drugs was expressed as the percentage decrease in the increase in PP induced by NE. $\mathrm{PP}$ variations among experimental groups are presented as average \pm standard error for the number of rats and were compared using Bonferroni unpaired test. A value of $P$ less than 0.05 was used to indicate significance.

\section{RESULTS AND DISCUSSION}

Chromatographic profiles of $A$. zerumbet and $A$. purpurata hydroalcoholic extracts indicated flavonoids which were suggested as contributing for antihypertensive vasodilator effects of $A$. zerumbet (Mpalantinos et al., 1998; Victório et al., 2009b). The content of rutin and kaempferol-3-O- $\beta$-D-glucuronide in dried extracts of $A$. zerumbet and A. purpurata leaves is shown in Table I. Higher kaempferol-3- $O$ - $\beta$-D-glucuronide content was found in leaves of $A$. zerumbet $\left(4.74 \mathrm{mg} .100 \mathrm{mg}^{-1}\right.$ dried extract) compared to A. purpurata extracts $\left(0.20 \mathrm{mg} .100 \mathrm{mg}^{-1}\right.$ dried extract). The increasing in total phenolics was ob- served in A. zerumbet cultured in control medium $(66.8 \mu \mathrm{g}$ GAE. $\mathrm{mg}^{-1}$ ), while plantlets maintained under IAA 2 treatment produced lower than $50 \%$ of phenolics $(26.2 \mu \mathrm{g}$ GAE. $\mathrm{mg}^{-1}$ ) (Table I). These data are in accordance with the high or low effect of $A$. zerumbet extracts from tissue cultures on MVB. The production of phenolic compounds through tissue cultures has been verified in studies with different medicinal plants (Konczak-Islam et al., 2003; Victório et al., 2008). Phenolic compounds are antioxidants responsible for free radical scavenging, capable of minimizing the damaging effects of reactive oxygen species, and considered potential compounds to preventing cardiovascular diseases (Khan, Mukhtar, 2007).

\section{Vasodilator effect of Alpinia purpurata extracts}

Isolate rat MVB was perfused with PSS solution, at $4 \mathrm{~mL} / \mathrm{min}$, and presented basal average perfusion pressure around 25 to $30 \mathrm{mmHg}$. Functionally, the in bolus injection of $120 \mu \mathrm{mol}$ of $\mathrm{KCl}$ increased the perfusion pressure up to $80 \mathrm{mmHg}$ and demonstrated the viability of MVB preparation. Addition of $30 \mu \mathrm{M}$ of NE in the perfusion solution induced firstly an increase of perfusion pressure, and then maintained it constant, in the level of 84 to $120 \mathrm{mmHg}$; which has enabled the study of vasodilator effect of hydroalcoholic extract of $A$. purpurata. The in bolus administration of $10 \mathrm{pmol}$ of $\mathrm{ACh}$ and $10 \mathrm{nmol}$ of $\mathrm{NG}$ decreased the perfusion pressure, confirming the integrity of endothelium and vascular smooth muscle, respectively. The administration of increasing doses of $A$. purpurata extract $(3,6,10,30$, and $60 \mu \mathrm{g})$ produced a dose-dependent vasodilator effect of long-lasting duration, similar to patterns of response of $A$. zerumbet extracts (Soares de Moura et al., 2005) (Figure 1). The response risen as the dose increased from $6 \mu \mathrm{g}$ upward (Figure 2). Vasodilator

TABLE I - Flavonoids content in hydroalcoholic extracts of leaves of field-grown A. purpurata and Alpinia zerumbet cultured in vitro

\begin{tabular}{|c|c|c|c|c|c|}
\hline Plant species & Origin & $\begin{array}{l}\text { Total phenolics* } \\
\left(\mu \mathrm{g} \text { GAE. } \mathrm{mg}^{-1}\right)\end{array}$ & $\begin{array}{c}\mathrm{RT} \\
(\mathrm{min})\end{array}$ & Rutin & $\begin{array}{l}\text { Kaempferol-3- } O \text { - } \beta \text {-D-glucuronide } \\
\text { mg }^{-1} \text { dried extract) }\end{array}$ \\
\hline \multirow{6}{*}{ A. zerumbet } & Field & $58.1 \pm 3.6$ & 31.23 & 0.48 & - \\
\hline & & & 34.77 & - & 4.74 \\
\hline & In vitro & & & & \\
\hline & MS0 & $66.8 \pm 3.4$ & & 0.0003 & 0.028 \\
\hline & IAA 2 & $26.2 \pm 2.0$ & & 0.024 & 0.018 \\
\hline & IAA $2+$ TDZ 2 & $43.7 \pm 1.4$ & & 0.134 & 0.032 \\
\hline \multirow{2}{*}{ A. purpurata } & Field & $30.1 \pm 1.8$ & 32.31 & 0.58 & \\
\hline & & & 35.52 & & 0.20 \\
\hline
\end{tabular}

RT - retention time. ${ }^{*}$ Average \pm SE. 
effect of hydroalcoholic extract of $A$. zerumbet was more effective, than that of $A$. purpurata extract verified in the present study; being reversed more than $50 \%$ of constrictive effect of NE, in the dose of $6 \mu \mathrm{g}$ (Emiliano, 2002). However, A. purpurata extracts have shown a rising and continuous relaxation (Figure 2), with the same intensity of results obtained for $A$. zerumbet in the dose of $60 \mu \mathrm{g}$ (Emiliano, 2002). The effects of $A$. purpurata extracts on MVB reached $87 \%$ potency at $60 \mu \mathrm{g}$ (Figure 2). The similarities respecting to response and vasodilator effect of these species could be related to presence of common secondary metabolites. The A. purpurata species, as well as the $A$. zerumbet, are natural sources of flavonoids, such as rutin, derived from quercetin, and the kaempferol-3- $O$ $\beta$-D-glucuronide. Both are referred for their typical vasodilator and anti-hypertensive actions (Formica, Regelson, 1995; Perez-Vizcaino et al., 2002; Xu et al., 2006). Recent researches conducted by Ferreira et al. (2007), showed that rutin is one of the main flavonoids in ethanolic extracts of Hancornia speciosa and that this extract has contributed for endothelium-dependent vasodilator activity in the mesenteric artery of rats. The endothelium-independent vasodilator action was also verified in studies with the flavonoid quercetin (Perez-Vizcaino et al., 2002).

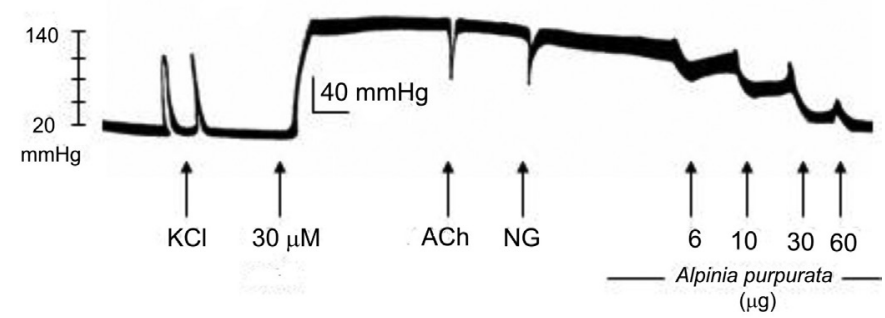

FIGURE 1 - Representative perfusion pressure ( $\mathrm{mmHg}$ ) trace showing the vasodilator effect of Alpinia purpurata hydroalcoholic extracts on MVB pre-contracted with NE $(30 \mu \mathrm{M})$ added to the perfusion fluid. Acetylcoline (Ach, 10 pmol) and Nitroglycerin (NG, $10 \mathrm{nmol}$ ) were also injected to test the endothelium-dependent and independent responses before dose-responses curves to extracts were obtained.

In studies developed by Emiliano (2002), it was suggested that the vasodilator effect of hydroalcoholic extract of $A$. zerumbet is endothelium-dependent, being it related to NO (nitrogen oxide) production, a vasodilator agent that acts increasing the activity of the enzyme soluble guanylate cyclase, which by its time, induces the production of cyclic guanosine monophosphate - the cGMP (Nagao, Vanhoutte, 1991). According to these results, the popular use of $A$. zerumbet in cases of arterial hypertension show positive responses, due to

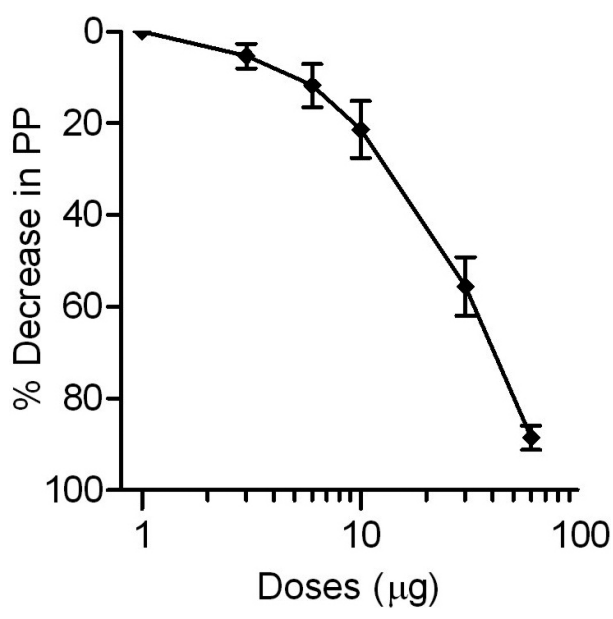

FIGURE 2 - Vasodilator effect of Alpinia purpurata hydroalcoholic extracts on MVB pre-contracted with NE. Each point represents the average $\pm S E, n \geq 6$.

action of the extract for decreasing the peripheral resistance (Emiliano, 2002). Such suggestion could be also conferred for the extract of $A$. purpurata, however, the results obtained are preliminary and other plant material collected from different geographic regions, and biological assays to confirm the species vasodilator effect, would be necessary. Mpalantinos (2001), in studies with aqueous extracts of $A$. zerumbet from different Brazilian regions, has obtained different results in relation to vasodilator activity. Inclusively, for some of these extracts of $A$. zerumbet, the vasodilator activity was lower than that for A. purpurata in current study (Figure 2). The environmental conditions exert some influence over the production of secondary metabolites, and this fact, in its turn, alters the dose-effect curves.

\section{Vasodilator effect of Alpinia zerumbet cultured in vitro}

A. zerumbet extracts obtained from in vitro cultures have shown different responses on MVB, but always with dose-dependent vasodilator standard of long-lasting duration (Figure 3 ). The extracts of $A$. zerumbet cultured in media containing plant growth regulators decreased the vasodilator effects compared to plantlets cultured in $\mathrm{MSO}$, except for treatment IAA $2+$ TDZ 2 in the doses of 30 and $60 \mu \mathrm{g}$. These findings may indicate the inhibitory effect of IAA $2 \mathrm{mg} . \mathrm{L}^{-1}$ on the production of secondary metabolites, as the isolated administration of IAA 2 resulted in inhibition higher than that of the combination IAA $2+$ TDZ 2. Extracts from plantlets maintained in control medium were more effective when inducing the vasodilator response with respect to other in vitro treatments, probably, 
due to higher concentration of phenolic compounds. The maximum response obtained for the extracts of plantlets from in vitro cultures was of $60 \%$ de relaxation in the dose of $90 \mu \mathrm{g}$, against $95 \%$ of field plants at $60 \mu \mathrm{g}$. Although tissues culture techniques constitute an important tool for the large scale production of plant raw material and in the optimized production of bioactive compounds as well, the results obtained for the in vitro production of secondary metabolites were not improved, even under the effect of growth regulators. However, important results could be suggested, with the inhibition of secondary metabolic pathways by the auxin IAA, in accordance with the decrease of total phenolics in extracts arising from this treatment.

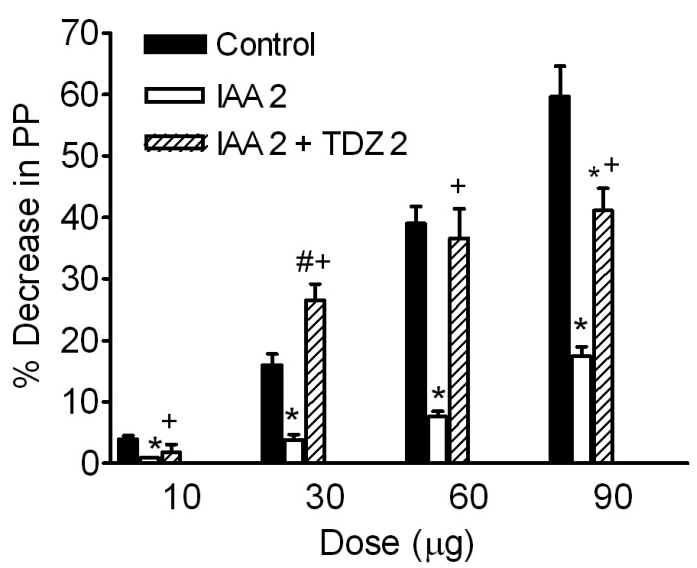

FIGURE 3 - Vasodilator effect of Alpinia zerumbet hydroalcoholic extracts obtained from in vitro cultures treated with different plant growth regulators on MVB pre-contracted with NE. *Value lower than control (MS0), "Value higher than control, ${ }^{+}$Higher response of IAA $2+$ TDZ 2 treatment compared to IAA 2. Each point represents the average $\pm \mathrm{SE}, \mathrm{n}$ $\geq 6$. Bonferroni, $P<0.05$.

\section{CONCLUSION}

Although the hydroalcoholic extracts of A. purpurata have shown vasodilator action, the required efficiency and potency combination to enable the production of a drug was not obtained. The studies are preliminary. However, phenolic compounds and flavonoids were detected for A. purpurata species, which has not excluded it as a possible natural source for obtaining bioactive compounds useful against hypertension.

No treatment with plant growth regulators has induced higher production of flavonoids in A. zerumbet plantlets, which probably are the responsible agents for the vasodilator effect. But the higher concentration of phenolic compounds verified in leaves of plantlets cultured in MS0 medium has resulted in a better vasodilator effect.

\section{ACKNOWLEDGMENTS}

C.P. Victório acknowledges the $\mathrm{PhD}$ fellowship and financial support from CAPES- PROAP/PROEX. The authors are especially grateful to Andrea Emiliano, Lenize Carvalho, Cristiane Aguiar and Lúcia Alves, who helped them in pharmacology tests.

\section{REFERENCES}

CANTER, P. H.; THOMAS, H.; ERNST, E. Bringing medicinal plants into cultivation: opportunities and challenges for biotechnology. Trends Biotechnol., v. 23, n.4, p.181-185, 2005.

DA COSTA, L. A. M. A.; MORAIS, S. M.; DANTAS, M. C. B. R.; LOBO, R. A. C. M.; FONTELES, M. C. Flavonóides com atividade hipotensora de Alpinia zerumbet (Pers.) Burt et Smith (colônia). Rev. Bras. Farmacol., v.79, n.3/4, p.96-98, 1998.

EMILIANO, A. F. Efeito vasodilatador do extrato hidroalcoólico da Alpinia zerumbet (Pers.) Burtt et Smith no leito vascular mesentérico de rato. Rio de Janeiro, 2002. 74 f. [Dissertação de Mestrado. Faculdade de Ciências Médicas. Universidade do Estado do Rio de Janeiro].

FERREIRA, H. C.; SERRA, C. P.; ENDRINGER, D. C.; LEMOS, V. S.; BRAGA, F. C.; CORTES, S. F. Endoteliumdependent vasodilation induced by Hancornia speciosa in rat superior mesenteric artery. Phytomedicine, v.14, n.7, p.473-478, 2007.

FORMICA, J. V.; REGELSON, W. Review of biology of quercetin and related bioflavonoids. Food Chem. Toxicol., v.33, n.12, p.1061-1080, 1995.

GODOY, M. F.; LUCENA, J. M.; MIQUELIN, A. R.; PAIVA, F. F.; OLIVEIRA, D. L. Q.; JUNIOR, J. L. A.; NETO, F. C. Mortalidade por doenças cardiovasculares e níveis socioeconômicos na população de São José do Rio Preto, estado de São Paulo, Brasil. Arq. Bras. Cardiol., v.88, n.2, p.200-206, 2007.

HAVSTEEN, B. H The biochemistry and medical significance of the flavonoids. Pharmacol. Ther., v.96, n.2/3, p.67-202, 2002.

KAISER, S. E. Aspectos epidemiológicos nas doenças coronariana e cerebrovascular. Rev. SOCERJ, v.17, n.1, p.11-18, 2004. 
KHAN, N.; MUKHTAR, H. Tea polyphenols for health promotion. Life Sci., v.81, n.7, p.519-533, 2007.

KONCZAK-ISLAM, I.; OKUNO, S.; YOSHIMOTO, M.; YAMAKAWA, O. Composition of phenolics and anthocyanins in a sweet potato cell suspension culture. Biochem. Eng. J., v.14, n.3, p.155-161, 2003.

LAHLOU, S.; GALINDO, C. A.; LEAL-CARDOSO, J. H.; FONTELES, M. C.; DUARTE, G. P. Cardiovascular effects of the essential oil of Alpinia zerumbet leaves and its main constituent, terpinen-4-ol, in rats: role of the autonomic nervous system. Planta Med., v.68, n.12, p.1097-1102, 2002.

LAHLOU, S.; INTERAMINENSE, L. F. L.; LEAL-CARDOSO, J. H.; DUARTE, G. P. Antihypertensive effects of the essential oil of Alpinia zerumbet and its main constituent, terpinen-4-ol, in DOCA-salt hypertensive conscious rats. Fundam. Clin. Pharmacol., v.17, n.3, p.323-330, 2003.

MCGREGOR, D. D. The effect of sympathetic nerve stimulation on vasoconstrictor response in perfused mesenteric blood vessels of the rat. J. Physiol., v.177, n.1, p.21-30, 1965.

MCNEILL, J. R.; JURGENS, T. M. A systematic review of mechanisms by which natural products of plant origin evoke vasodilatation. Can. J. Physiol. Pharmacol., v.84, n.8/9, p.803-821, 2006.

MENDONÇA, V. L. M.; OLIVEIRA, C. L. A.; CRAVEIRO, A. A.; RAO, V. S.; FONTELES, M. C. Pharmacological and toxicological evaluation of Alpinia speciosa. Mem. Inst. Oswaldo Cruz, v.86, n.2, p.93-97, 1991.

MPALANTINOS, M. A.; SOARES DE MOURA, R.; PARENTE, J. P.; KUSTER, R. M. Biologically active flavonoids and kava pyrones from the aqueous extract of Alpinia zerumbet. Phytotherapy, v.12, n.6, p.442-444, 1998.

MPALANTINOS, M. A. Identificação de substâncias antihipertensivas de Alpinia zerumbet Pers. Rio de Janeiro, 2001. 197 p. [Tese de Doutorado em Produtos Naturais. Núcleo de Pesquisas de Produtos Naturais. Núcleo de Pesquisas de Produtos Naturais. Universidade Federal do Rio de Janeiro].

MURASHIGE, T.; SKOOG, F. A revised medium for rapid growth and bioassays with tobacco tissue cultures. Physiol. Plant., v.15, n.3, p.473-497, 1962.
NAGAO, T.; VANHOUTTE, P. M. Hyperpolarization contributes to endothelium-dependent ralaxations to acetylcholine in femoral vein of rats. Am. J. Physiol., v.261, n.4, p.1034-1037, 1991.

PEREZ-VIZCAINO, F.; IBARRA, M.; COGOLLUDO, A. L.; DUARTE, J.; ZARAGOZA-ARNAEZ, F.; MORETNO, L.; LOPEZ-LOPEZ, G.; TAMARGO, J. Endotheliumindependent vasodilator effects of the flavonoid quercetin and its methylated metabolites in rat conductance and resistance arteries. J. Pharmacol. Exp. Ther., v. 302, n.1, p.66-72, 2002.

PUGiAlli, H. R. L.; KAPLAN, M. A. C.; GOTTLIEB, O. R. Chemotaxonomy of superorder Zingiberiflorae (sensu Dahlgren) I. Flavonoids. Acta Bot. Bras., v.7, n.2, p.135148, 1993.

POURCEL, L.; ROUTABOUL, J. M.; CHEYNIER, V.; LEPINIEC, L.; DEBEAUJON, I. Flavonoid oxidation in plants: from biochemical properties to physiological functions. Trends Plant Sci., v.12, n.1, p.29-36, 2006.

ROCHA, A. P. M.; CARVALHO, L. C. R. M.; SOUSA, M.A. V.; MADEIRA, S. V. F.; SOUSA, P. J. C.; TANO, T.; SCHINIKERTH, V. B.; RESENDE, A. C.; SOARES DE MOURA, R. Endothelium-dependent vasodilator effect of Euterpe oleracea Mart. (Açai) extracts in mesenteric vascular bed of the rat. Vasc. Pharmacol., v.46, n.2, p.97-104, 2007.

SINGLETON, V. L.; ROSSI, J. A. J. R. Colorimetry of total phenolics with phosphomolybdic-phosphotungstic acid reagents. Am. J. Enol. Vitic., v.16, n.3, p.144-158, 1965.

SOARES DE MOURA, R.; AFIATPOUR, P.; DA SILVEIRA, A. V.; DE MELLO, R. G.; NETO, M. D.; ALMAGRO, L. C. Effect of hydroalcoholic extract of colonia (Alpinia zerumbet) on rat arterial blood pressure and on the isolated human saphenous vein. Naunyn-Schmiedeberg 's Arch. Pharmacol., v. 358, n.1, p.3844, 1998.

SOARES DE MOURA, R.; EMILIANO, A. F.; CARVALHO, L. C. R.; SOUZA, M. A. V.; GUEDES, D. C. Antihypertensive and endothelium-dependent vasoditlation effects of Alpinia zerumbet, a medicinal plant. J. Cardiovasc. Pharmacol., v.46, n.3, p.288-294, 2005.

WANG, S.; DUSTING, G. J.; WOODMAN, O. L.; MAY, C. N. Selective vasodilator and chronotropic actions of 3', 4'-dihydroxyflavonol in conscious sheep. Eur. J. Pharmacol., v.491, n.1, p.43-51, 2004. 
VICTÓRIO, C. P.; KUSTER, R. M.; LAGE, C. L. S. Detecção de flavonóides de Alpinia purpurata por CCD e CLAE. JBF. J. Bras. Fitoter., v.5, n.3, p.137, 2007.

VICTÓRIO, C. P. Cultura de tecidos e metabólitos especiais em colônia (Alpinia zerumbet Pers. Burtt et Smith) e A. purpurata (Vieill) K. Schum e estudos preliminares de atividade biológica. Rio de janeiro, 2008. 186 f. [Tese de Doutorado em Ciências Biológicas - Biofísica. Instituto de Biofísica Carlos Chagas Filho. Universidade Federal do Rio de Janeiro].

VICTÓRIO, C. P.; DA CRUZ, I. P.; SATO, A.; KUSTER, R. M.; LAGE, C. L. S. Effects of auxins and cytokinins on in vitro development of Alpinia purpurata (Vieill) K. Schum and phenolic compounds production. Plant Cell Cult. Micropropag. v.4, n.2, p.5-9, 2008.

VICTÓRIO, C.P.; RIEHL, C. A. S; LAGE, C. L. S. Simultaneous distillation-extraction, hydrodistillation and static headspace methods for the analysis of volatile secondary metabolites of Alpinia zerumbet (Pers.) Burtt et Smith. from Southeast Brazil. J. Ess. Oil Bear. Plants, v.12, n.2, p.137-143, 2009a.
VICTÓRIO, C. P.; KUSTER, R. M.; LAGE, C. L. S. Detection of flavonoids in Alpinia purpurata (Vieill) K. Schum. leaves by high-performance liquid chromatography. Braz. J. Med. Plant, v.11, n.2, p.147-153, 2009b.

XU, Y. C.; YEUNG, D. K. Y.; MAN, R. Y. K.; LEUNG, S. W. S. Kaempferol enhances endothelium-independent and dependent relaxation in the porcine coronary artery. Mol. Cell. Biochem., v.287, n.1/2, p.61-67, 2006.

ZHENG-TAO, W.; CHI-WAI, L.; LEUNG, F.; XIAOQIANG, Y.; ZHEN-YU, C.; ZHEN-DAN, H.; YU, H. Vasorelaxant effects of cardamonin anda alpinetin from Alpinia henryi K. Schum. J. Cardiovas. Pharmacol., v.37, n.5, p.596-606, 2001.

Received for publication on $25^{\text {th }}$ June 2008 Accepted for publication on $14^{\text {th }}$ April 2009 